\title{
Inclination of Teachers towards Incorporating Mobile Game Based Learning into Primary Education: A Sri Lankan Case Study
}

\author{
Pradeepa S. Bandara \\ Faculty of Computing, Department of Information Technology, Sri Lanka Institute of Information \\ Technology (SLIIT), Malabe, 10115, Sri Lanka \\ E-mail: pradeepabandara@gmail.com
}

Received: 20 December 2017; Accepted: 09 March 2018; Published: 08 April 2018

\begin{abstract}
Incorporating information and communication technology (ICT), especially computer/mobile games into teaching and learning has been identified as a proven method of increasing primary grade students' intrinsic motivation towards learning. However, in countries like Sri Lanka with teacher centric education cultures, the teacher still plays a significant role in the child's education process. Therefore, it is imperative to look at the teachers' willingness and inclination to integrate technology enhanced games in their classrooms. The purpose of this study is to investigate the teachers' preparedness, attitude towards integrating mobile games in teaching and the issues faced by the teachers when trying to use technology in the Sri Lankan primary classroom. A questionnaire for assessing mobile game based learning readiness was designed and used as the research instrument to assess the inclination of teachers to incorporate mobile-based games for learning in their classroom. The survey was conducted involving primary school teachers in four Type 3 schools of Gampaha district in Sri Lanka. Type 3 schools have classes only up to grade 8. It was identified that the teachers in Type 3 schools of Gampaha district are moderately inclined towards incorporating mobile games into their day-to-day teaching activities.
\end{abstract}

Index Terms-Teacher readiness, Mobile game based learning, Technology enhanced education, Primary education with games, Sri Lankan primary education.

\section{INTRODUCTION}

We hypothesized introduction of tablet based games that managed through a learning management system could potentially provide a solution for the issues identified in primary education of developing countries [1]. The paper focused on the effects of using tablet computer device based edutainment systems on students' motivation, attitude, and achievements within the context of primary mathematical education in Sri Lanka. Grade 3 students were selected for the study according to Jean Piaget's stages of cognitive development theory [2].
According to this theory, a child acquires the ability to do mental operations around the age of 8 years in other terms, grade 3.

However, during the process of planning the study and identifying a suitable sample for the experiment, the researchers found that even though the students are excited about using tablet devices in the classroom, some of the teachers were hesitant. This study aims to fill in the contextual gaps identified in previous studies, created by the low ICT literacy levels of teachers and lack of focus on Primary schools. It also attempts to identify the inclination of teachers towards incorporating mobile game based learning as well as factors that may contribute to it, in order to address those factors before embarking on the proposed interventional study suggested by Halloluwa, Usoof and Hewagamage [1].

There are four categorizations of schools in Sri Lanka, namely $1 \mathrm{AB}, 1 \mathrm{C}$, Type 2 and Type 3 [3]. $1 \mathrm{AB}$ are the schools that have Advanced Level Science stream classes in addition to Commerce and Art streams. 1C is where only Advanced Level Commerce and Art streams are available. Type 2 has classes only up until grade 11 whereas Type 3 schools have classes only up to grade 8 . Type 3 schools were selected for this study because overall, students and the teachers of these schools have very limited exposure to computers and tablet devices.

Overall, this study focuses on the following research question:

RQ: What are the factors that may contribute to teachers' inclination towards incorporating mobile game base learning into their teaching?

For the purpose of the study, we have collected questionnaire data from five primary schools in the Gampaha district. While the contribution of this paper is to report how inclined the teachers in the selected Type 3 schools of Gampaha district in Sri Lanka were to incorporate mobile games to their day-to-day teaching, along with the factors that affect their inclination, we point out that these findings should not be generalized to all the primary schools and primary teachers in Sri Lanka. 


\section{RELATED WORKS}

Few studies have been carried out in a similar context, which focuses on the inclination of teachers to use computers in teaching, though the results were inconclusive [4], [5]. However, there were studies that suggest that the usage of computer devices inspire the teachers to carry out their tasks with greater sense of purpose [6], [7]. Nonetheless, the notion of using computer-aided tools in teaching is facing high resistance by the teachers in many countries even though there are enough studies that prove the usage of devices would increase the opportunity to learn and increase students' achievements [4], [8]. Thus, it is reasonable to assume that the acceptance of technology enhanced learning and integrating mobile devices to learning varies due to various political and social conditions as well as attitudes and motivation. Furthermore, studies suggest that the way teachers are teaching depends on their own experience and schooling [9]. S.L Nyakowa [10] claims that it is unreasonable to expect teachers to integrate new approaches to teaching if they themselves are not provided with adequate training or experience.

While there is only limited research on inclination towards integrating mobile games into teaching, there exists a significant amount of research on the inclination of using e-learning. Therefore, researchers have decided to look deep in to the work done on measuring e-learning inclinations.

The Webster's New Collegiate Dictionary defines inclination as "a tendency to a particular aspect, state, character, or action". In the e-learning context, it can be defined as "the tendency of a particular organization, an individual or a group to use e-learning". Assessing the inclination for e-learning helps organizations to implement strategies and ICT, goals effectively [11] while providing information which helps develop elearning solutions for various learning groups.

There are few different models designed for assessing inclination for e-learning. In his research, Chapnick [12] introduces a model to measure e-leaning inclination by inquiring the following:

1. Can we do this?

2. If we can do this, how are we going to do it?

3. What are the outcomes and how do we measure them?

He presents a model designed to simplify the process of ascertaining the basic information needed to answer the above questions. His model includes eight categories;

1. Psychological inclination: Considers the individual's state of mind.

2. Sociological inclination: Considers the interpersonal relationships of the environment, where the study is carried out.

3. Environmental inclination: Considers the external and internal influences to the stakeholders of the organization.
4. Human resource inclination: Considers the availability of a support system.

5. Financial inclination: Considers the budget allocation.

6. Technological skill inclination: Considers technical competencies.

7. Equipment inclination: Considers the availability of the required equipment.

8. Content inclination: Considers the subject matter.

However, one major flaw of this model in the context of teachers is that this model is specifically designed for corporate environments, not academic environments.

Another model displaying similarities with Chapnik's model is one designed by Kaur and Abas [11]. Their model was used to assess the inclination of the teachers of Open University Malaysia, where eight categories of inclination; learner, management, personnel, content, technical, environmental, cultural and financial, were focused on.

Taking a slightly different approach, Borotis and Poulymenakou [13] proposed a seven-component model of e-learning inclination, based on previous research and their own experience.

Few other models for assessing e-learning inclination are listed below.

1. Haney Model: Introduced seventy questions to be asked, which are classified into seven categories; Human resources, learning management system, learners, content, information technology, finance, and vendor [14].

2. Fetaji Model: Consists of seven indicators, where they address Learners' education and cultural background, learners' computing skills, learners' learning preferences, the quality of e-learning content, viable learning environment, and its elearning logistics, learners' motivation, students' attitudes toward technology [15].

3. STOPE Model: This is an illustrative representation and addresses Leadership, Technology, Organization, People, and Environment [16].

4. Li-An Ho Model: presents a model with four main categories that are, e-learning system quality, technology inclination, learning behavior, and learning outcome [17].

Kocaleva, Stojanovic, and Zdravev [18] identify seven determinants of staff acceptance and use e- Learning system. They claim that the effort expectancy and facilitating conditions have the most impact of intention to use new technology. Furthermore, Yuen and Ma [17] have found that the teachers' gender is a factor that has a correlation with the inclination to use technology in teaching. Their results indicate that males consider computers as a masculine domain and shows greater confidence with using technology than female teachers [19].

It is, however, important to note that the majority of 
these studies are carried out in countries where computer literacy of the population is high compared to countries such as Sri Lanka. Only 16.4 percent of households possess a computer and only 22 percent of the individuals are using the Internet, both mobile broadband and fixed lines [20]. According to a recent survey conducted by the Department of Census and Statistics Sri Lanka, 25.1 percent of the population is considered computer literate [21]. The below table clearly shows the digital divide in Sri Lanka where 34.6 percent of the urban population is computer literate and only 6.2 percent of the estate population is computer literate.

Table 1. Digital Divide Sri Lanka (Census, 2014)

\begin{tabular}{|l|l|}
\hline \multicolumn{1}{|l|}{ Sri Lanka } & $\mathbf{2 5 . 1}$ \\
\hline Sector & 34.6 \\
\hline Urban & 23.8 \\
\hline Rural & 6.2 \\
\hline Estate & \\
\hline Province & 34.3 \\
\hline Western & 24.3 \\
\hline Central & 25.4 \\
\hline Southern & 17.5 \\
\hline Northern & 15.9 \\
\hline Eastern & 22.6 \\
\hline North Western & 15.3 \\
\hline North Central & 17.1 \\
\hline Uva & 22.6 \\
\hline Sabaragamuwa & \\
\hline
\end{tabular}

A further contextual difference of the existing research is that a majority of the previous studies have focused on teachers in secondary or tertiary education (i.e. [18], [22]) However, researchers have claimed that technology can be used for greater gains at primary schools as well if applied properly [23], [24], [25], [36]. Yet, it is clear that in the primary school, teachers play a significant role in a child's education [27], [28]. In this case, the researchers are primarily focusing on identifying the gaps and barriers towards primary teachers' inclination to incorporate mobile games in to teaching.

Based on the previous research, a model was designed which was used to determine the inclination of teachers towards integrating mobile game based learning in primary education. The model consists of six primary categories and a set of sub categories as tabulated below.
Table 2. Questionnaire Categories

\begin{tabular}{|c|}
\hline Category 01: Teacher's experience \\
\hline Teachers experience and technical skills \\
\hline Teacher's exposure to technology \\
\hline Teacher's preferences in teaching \\
\hline Category 02: Teacher's preparedness \\
\hline Awareness of Game Based Learning \\
\hline Awareness of using mobile devices as a teaching tool \\
\hline Willingness to integrate technology into school curriculum \\
\hline Category 03: Teacher's attitudes \\
\hline Towards using mobile devices in class room \\
\hline Towards using games in teaching \\
\hline Ability to spend time after school, getting ready \\
\hline Willingness to work with new technology \\
\hline Category 04: School culture \\
\hline Knowledge sharing among teachers \\
\hline Level of encouragement from the colleagues \\
\hline Category 05: Infrastructure, budget, and equipment \\
\hline Ability to acquire required equipment. \\
\hline Ability to get internet access, electricity to school \\
\hline Ability to pay utility bills \\
\hline Ability to hire technicians when and if something went wrong \\
\hline Category 06: Management support \\
\hline The level of encouragements by the management \\
\hline
\end{tabular}

\section{METHOD}

A descriptive and a non-parametric study was carried out to analyze the survey data. David and Kenneth [29] defined a descriptive study as a situation where a descriptive data analysis is obtained from the questionnaires or other media. Descriptive methods such as frequencies and cross tabulations were used along with non-parametric analysis methods such as Friedman's test. A questionnaire was used to gather data for this study with 37 teachers involved in primary school teaching. The teachers are from five primary schools in Gampaha district and only 30 teachers contributed in providing information for the study. Information about teachers' experience in teaching, ICT skills and exposure to technology was taken along with fifteen other items on a Likert scale with a continuum from "1" equivalent to "strongly disagree" and "5" represented "strongly agree". The items in the questionnaire were adapted from prior studies done on e-learning inclination in different countries. Hence, it can be argued that the instrument used in the study is reasonably reliable. Fifty-three percent of the respondents were male teachers and 47 percent of the respondents were females. 


\section{RESULTS AND ANALYSIS}

The following hypotheses were put forward in order to formulate answers to the research questions;

$\mathrm{H}_{1}$ : There is a significant relationship between a teacher's inclination to incorporate mobile games in to their teaching and the overall teaching experience.

$\mathrm{H}_{2}$ : There is a significant relationship between a teacher's inclination to incorporate mobile games in to their teaching and the teaching experience at the current school

$\mathrm{H}_{3}$ : There is a significant relationship between a teacher's inclination to incorporate mobile games in to their teaching and their gender.

$\mathrm{H}_{5}$ : There is a significant relationship between a teacher's inclination to incorporate mobile games in to their teaching and their ICT skills.

$\mathrm{H}_{6}$ : There is a significant relationship between a teacher's inclination to incorporate mobile games in to their teaching and their awareness of using mobile devices in teaching.

$\mathrm{H}_{7}$ : There is a significant relationship between a teacher's inclination to incorporate mobile games in to their teaching and their awareness of using digital games in teaching.

$\mathrm{H}_{8}$ : There is a significant relationship between a teacher's inclination to incorporate mobile games in to their teaching and their ownership of a PC or a laptop.

$\mathrm{H}_{9}$ : There is a significant relationship between a teacher's inclination to incorporate mobile games in to their teaching and their ownership of a smart device.

$\mathrm{H}_{10}$ : There is a significant relationship between a teacher's inclination to incorporate mobile games in to their teaching and the support of the management.

The data were analyzed using the SPSS software. Descriptive statistics such as percentage mean and standard deviations are used to simplify the sample information involved in determining teachers' inclination towards the use of mobile game based learning and integrating it with their teachings. The above mentioned hypotheses were tested using a non-parametric Friedman test with a Chi-square analysis. Even though the variable worked with are of an ordinal type, a Kruskal Wallis test was not done because the data did not conform to a normal distribution. Along with the Freidman test, Spearman's Rank-Order Correlation was carried out to identify relationships between variables.

As for the teaching experience, 77 percent of the respondents have been teaching over 10 years and only 33 percent have been teaching for less than 10 years. Of those teaching below 10 years, only 6 percent of the teachers have been teaching for less than 5 years. Thirtythree percent of the respondents owned a personal computer. However, only 13 percent of the teachers were familiar with using a smart phone while the others use a keypad mobile phone. None of them had used a tablet computer. Only 7 percent of the teachers claimed they have good ICT skills while 93 percent perceived themselves to have weak or average ICT skills. No respondents were very good or very weak in ICT. None of the respondents have had any formal ICT training.

Table 3. Demographic Information about the teachers

\begin{tabular}{|cccc|}
\hline & Frequency & Percentage \\
\hline Gender & Male & 16 & \\
& Female & 14 & 53.3 \\
& & 46.7 \\
\hline Teaching Experience & 18 & \\
> 20 years & 2 & 60.0 \\
15-20 years & 3 & 6.7 \\
10-14 years & 5 & 10.0 \\
5-9 years & 2 & 16.7 \\
< 5 years & & 6.7 \\
\hline Keypad Phones & 26 & 86.7 \\
Smart Phones & 4 & 13.3 \\
\hline Use of Computers & & \\
Yes & 20 & 66.7 \\
No & 10 & 33.3 \\
\hline
\end{tabular}

The following results were obtained for the null hypothesizes with the Chi-square test.

Table 4. Hypothesis Testing

\begin{tabular}{|l|c|}
\hline & P \\
\hline $\begin{array}{l}\text { Teacher's overall teaching experience and inclination } \\
\text { to incorporate mobile games in to their teaching are } \\
\text { independent }\end{array}$ & 0.0001 \\
\hline $\begin{array}{l}\text { Teacher's teaching experience at the current school and } \\
\text { inclination to incorporate mobile games in to their } \\
\text { teaching are independent }\end{array}$ & 0.0593 \\
\hline $\begin{array}{l}\text { Teacher's gender and inclination to incorporate mobile } \\
\text { games in to their teaching are independent. }\end{array}$ & 0.0000 \\
\hline $\begin{array}{l}\text { Teacher's ICT skills and inclination to incorporate } \\
\text { mobile games in to their teaching are independent. }\end{array}$ & 0.0002 \\
\hline $\begin{array}{l}\text { Teacher's awareness of using mobile devices in } \\
\text { teaching and inclination to incorporate mobile games } \\
\text { in to their teaching is independent. }\end{array}$ & 0.0000 \\
\hline $\begin{array}{l}\text { Teacher's awareness of using digital games in teaching } \\
\text { and inclination to incorporate mobile games in to their } \\
\text { teaching is independent. }\end{array}$ & 0.0000 \\
\hline $\begin{array}{l}\text { Teacher's ownership of a PC or a laptop and } \\
\text { inclination to incorporate mobile games in to their } \\
\text { teaching are independent }\end{array}$ & 0.0000 \\
\hline $\begin{array}{l}\text { Teacher's ownership of a smart device and inclination } \\
\text { to incorporate mobile games in to their teaching are } \\
\text { independent. }\end{array}$ & 0.0000 \\
\hline $\begin{array}{l}\text { Management support and inclination to incorporate } \\
\text { mobile games in to their teaching are independent. }\end{array}$ & 0.0003 \\
\hline
\end{tabular}

The above results suggest that there is a significant correlation between the inclination towards incorporating mobile games into teaching, and the teachers' overall teaching experience, gender, ICT skills, awareness of using mobile devices in teaching, awareness of using digital games in teaching, ownership of a PC or a laptop and the ownership of a smart device. The support of the principal plays a significant role as well. However, it also indicates there is no significant correlation between the teachers teaching experience in the current school they are teaching and their inclination towards incorporating mobile games in to teaching. 
A simple descriptive study shows that it is the teachers with more than 15 years of experience who are more inclined towards incorporating mobile games. From those, the male teachers are more inclined than the female teachers. Furthermore, the results indicate that the teachers with good or very good ICT competencies are more inclined towards incorporating mobile games into their teaching and their awareness and ownership of devices is another factor.

In relation to a blended learning approach, 46 percent of the respondents said that they prefer a combination of more classroom teaching (face-to-face) and less online teaching (with the use of online materials and other technological equipment) while 50 percent responded, indicating they prefer an equal amount of classroom teaching and online teaching. None said they prefer teaching full time in a classroom using only the traditional methods.

With regard to the position on a mobile game based learning, 73.3 percent responded indicating they believe mobile game based learning will make a positive difference in students' interest in learning while 90 percent of them said it will make a positive difference in the delivery of the course's content. However, 13 percent of the respondents stated that they believe it's a waste of time trying to integrate mobile game based learning in their teaching mainly because they believed that they have the ability to use traditional teaching techniques to teach anything better than that can be taught using mobile games.

Table 5. Item Analysis of attitudinal, environmental, institutional and social factors

\begin{tabular}{|c|c|c|}
\hline & Item & Mean \\
\hline 1 & $\begin{array}{l}\text { I look forward to learning new skills and } \\
\text { applying them in my teaching. }\end{array}$ & 4.17 \\
\hline 2 & $\begin{array}{l}\text { I am ready to integrating games running on } \\
\text { mobile devices in my teaching }\end{array}$ & 4.00 \\
\hline 3 & $\begin{array}{l}\text { A mobile game based learning will make a } \\
\text { positive difference in my students' interest in } \\
\text { learning. }\end{array}$ & 3.83 \\
\hline 4 & $\begin{array}{l}\text { A mobile game based learning will make a } \\
\text { positive difference in the delivery of my } \\
\text { course's content. }\end{array}$ & 4.07 \\
\hline 5 & $\begin{array}{l}\text { I can find at least } 2 \text { hours a week to devote to } \\
\text { this course outside of class time. }\end{array}$ & 3.47 \\
\hline 6 & $\begin{array}{l}\text { I believe it's possible for me to acquire } \\
\text { technical skills required for teach using games } \\
\text { running on mobile devices }\end{array}$ & 3.23 \\
\hline 7 & $\begin{array}{l}\text { I am confident that I will be able to } \\
\text { successfully adopt mobile game based } \\
\text { learning initiatives in my courses if given the } \\
\text { necessary resources and training support. }\end{array}$ & 3.93 \\
\hline 8 & $\begin{array}{l}\text { I feel confident that the mobile game based } \\
\text { learning will help students understand } \\
\text { concepts better. }\end{array}$ & 3.53 \\
\hline 9 & $\begin{array}{l}\text { The IT infrastructure in my school can } \\
\text { support mobile game based learning }\end{array}$ & 3.43 \\
\hline 10 & $\begin{array}{l}\text { Other teachers encourage me to integrate } \\
\text { computers in teaching and learning }\end{array}$ & 3.60 \\
\hline 11 & $\begin{array}{l}\text { There are other teachers in my school who } \\
\text { use tablet computers in teaching and learning }\end{array}$ & 3.30 \\
\hline
\end{tabular}

When considering the infrastructure, 16.7 percent of the respondents suggested that their schools do not have the necessary infrastructure such as electricity and broadband Internet connection to support mobile game based learning. However, all of the participants stated that their schools could not afford the cost of purchasing the devices.

Referring to management and institutional support, 80 percent responded stating that the school management encourages them to incorporate new technologies and techniques in teaching. Of the respondents, 97 percent stated that they are confident in their ability to successfully adopt mobile game based learning initiatives in their teaching courses if the necessary resources and training support is provided.

An item analysis is carried out to see the teachers' overall inclination towards the application of mobile games in teaching. Determination of the level of inclination of the respondents is conducted based on the mean average.

The results indicate that the inclination to incorporate mobile games in to teaching of Type 3 school teachers of the selected schools in the Gampaha district of Sri Lanka is on the moderate level, with a mean average of 3.69.

\section{DISCUSSION AND CONCLUSION}

This study indicates that the participants surveyed have a high inclination towards integrating mobile game based learning in their day-to-day teaching activities if the required technical knowledge, skills infrastructure are provided. The research instrument was formulated incorporating multiple available instruments that have been previously used to determine the inclination towards integrating mobile games in teaching.

In reference to the second research question, the study showed that there is a significant relationship between the inclinations towards integrating mobile game based learning in teaching and the teacher's teaching experience, gender, confidence in using ICT and the awareness about the use of mobile games for teaching.

Based on the findings and researchers' observations during the study, the following conclusions were made. Even though a significant amount of money and resources have been allocated into developing ICT infrastructure in the country [30] schools in Sri Lanka are at an initial stage of employing ICT in their day-to-day teaching activities. This is evident when the responses of teachers are analyzed in terms of the infrastructure support in the schools. While about 83.3 percent of the teachers stated that their school could afford the cost of electricity and broadband connection, most participants were not aware of exactly how much the school will have to spend to facilitate all the students. Having said that, all the teachers agreed that the schools could not afford to purchase equipment for supporting teaching and learning. Allocation of adequate funds for schools for at least supporting one class at a time and then building upon that could be a possible solution to the above problem.

Next, the school management should encourage teachers to continue developing technology-based skills. The study showed that the more competent teachers with 
technical skills are more inclined towards incorporating mobile games in to their teaching. Teachers' feedback can be taken to determine if they need to attend training programs since most teachers stated that they are willing to try mobile game based learning if the required training is provided. Furthermore, the management should encourage teachers to pursue teaching methods and techniques which link with ICT. The researchers suggest that the management introduce a program where the teachers who incorporate technology in to their teaching are recognized as this would encourage other teachers to follow.

The results also depict that the teachers' awareness of the usage of games and mobile devices in teaching plays a role in their inclination towards incorporating mobile games in to their teaching. Thus, the researchers suggest that the government organize awareness sessions in the schools stating the advantages it brings to students as well as teachers. The teachers who were not inclined specifically said mobile devices and games were both a waste of time for students and it should not be allowed in schools. This inaccurate perception could be remedied through the education of teachers about the advantages technology brings in supporting student learning.

It was found that the overall teaching experience of a teacher plays a role in their inclination to use mobile games to teach. The researchers also looked at whether the experience in the current school has any relationship towards using mobile games in teaching. This was done based on the assumption that when a teacher is new to a school, they might or might not be willing to bring change. However, no significant relationship was found between the two.

The gender factor showed a statistical significance for the inclination to use mobile games. However, from the data gathered, the researchers failed to identify a specific reason for this. This could be an effect of the teaching experience of the teachers, having 50 percent of the female teachers with less than 10 years' experience where as 81 percent of the male teachers have more than 20 years of experience.

The findings of this study should not be generalized to all the primary schools and primary teachers in Sri Lanka. However, the selected schools are of Type 3 category, and all the respondents had very limited or no exposure to tablet devices, with weak or average ICT skills. Therefore, it can be argued that the results and findings of the survey experiment are true to most teachers in Type 3 schools. A survey covering all Types and all districts of Sri Lanka could be used in the future to verify the above findings. This study comprised of factors broadly categorized into six categories; Teacher's experience, preparedness, attitudes, school's culture, infrastructure, and management support. However, this paper does not claim that these factors are the sole factors that have a relationship with an inclination towards integrating mobile game based learning in teaching. More factors may have a direct relationship with the inclination towards integrating mobile game based learning in teaching and future studies are required to identify all of them.

However, while several other countries with developed economies have carried out similar experiments and come up with varying results, it is clear that in countries such as Sri Lanka, the above mentioned factors play a key role in teachers' inclination towards incorporating mobile game based learning into their day to day teaching and learning activities.

\section{ACKNOWLEDGMENT}

The authors wish to thank the Western Provincial Department of Education, Sri Lanka, The University of Colombo School of Computing and all the teachers who participated in this study.

\section{REFERENCES}

[1] H. K. T. C. Halloluwa, H. Usoof, and K. P. Hewagamage, "Stimulating learners' motivation in primary education in Sri Lanka - A literature review," Int. J. Emerg. Technol. Learn., vol. 9, no. 1, pp. 47-52, 2014.

[2] J. H. Flavell, "Cognitive development: Past, present, and future.," Dev. Psychol., vol. 28, no. 6, p. 998, 1993.

[3] D. of C. and Statistics, "Annual Bulletin of Educational Statisctics 2010," Sri Lanka, 2010.

[4] P. J. H. Hu, T. H. K. Clark, and W. W. Ma, "Examining technology acceptance by school teachers: A longitudinal study," Inf. Manag., vol. 41, no. 2, pp. 227-241, 2003.

[5] M. A. K. Rahuman, G. N. Wikramanayake, and K. P. Hewagamage, "Case Study on Adaptability to ICT Enabled Childhood Education in Sri Lanka," Int. Conf. Adv. ICT Emerg. Reg., pp. 112-116, 2011.

[6] L. Schrum, G. Shelley, and R. Miller, "Understanding tech-savvy teachers: Identifying their characteristics, motivation, and challenges," Int. J. Technol. Teach. Learn., vol. 4, no. 1, pp. 1-20, 2008.

[7] T. Karsenti, S. Villeneuve, and S. Goyer, "The Impact of Motivation on Prospective Teachers' Use of Information and Communication Technologies (ICTs)," in Society for Information Technology \& Teacher Education International Conference, 2006, vol. 2006, no. 1, pp. 1659-1666.

[8] A. P. Rovai and M. D. Childress, "Explaining and Predicting Resistance to Computer Anxiety Reduction among Teacher Education Students," J. Res. Technol. Educ., vol. 35, no. 2, pp. 226-235, Dec. 2002.

[9] L. Nyakowa, "Factors influencing ICT adoption among public secondary school teachers: A case of Webuye subcounty, Bungoma county, Kenya," Unpublished Doctoral Dissertation, University of Nairobi, vol. 2010, no. 1. Association for the Advancement of Computing in Education (AACE), pp. 4051-4059, 17-May-2014.

[10] L. S. Nyakowa, "Factors influencing ICT adoption among public secondary school teachers: A case of Webuye subcounty, Bungoma county, Kenya," Int. Conf. Comput. Educ., 2014.

[11] K. Kaur and Z. W. Abas, "An assessment of e-learning readiness at Open University Malaysia," Int. Conf. Comput. Educ., pp. 1017-1022, 2004.

[12] S. Chapnick, "Are You Ready for E-Learning?," Learn. Circuits ASTD's Online Mag. All About ELearning, 2000.

[13] S. Borotis and A. Poulymenakou, "E-Learning Readiness Components: Key Issues to Consider Before Adopting eLearning Interventions," in Proceedings of E-Learn 2004-World Conference on E-Learning in Corporate, 
Government, Healthcare, and Higher Education, 2004, vol. 2004, no. 1, pp. 1622-1629.

[14] D. Haney, "Assessing Organizational Readiness for ELearning: 70 Questions To Ask," Perform. Improv., vol. 41, no. 4, pp. 10-15, 2002.

[15] B. Fetaji and M. Fetaji, "e- Learning Indicators: MultiDimensional Model for Planning and Evaluating $\mathrm{e}^{-}$ Learning Software Solutions," Electron. J. e-Learning, vol. 7, no. 2, p. 28, 2009.

[16] K. Al-Osaimi, A. Alheraish, and S. H. Bakry, "STOPEbased approach for e-readiness assessment case studies," Int. J. Netw. Manag., vol. 18, no. 1, pp. 65-75, Jan. 2008.

[17] L.-A. Ho, "The antecedents of e-learning outcome: an examination of system quality, technology readiness, and learning behavior," Adolescence, 2009.

[18] M. Kocaleva, I. Stojanovic, and Z. Zdravev, "Model of eLearning Acceptance and Use for Teaching Staff in Higher Education Institutions," Int. J. Mod. Educ. Comput. Sci., vol. 7, no. 4, pp. 23-31, 2015.

[19] G. Russell and G. Bradley, "Teachers' computer anxiety: implications for professional development. Education and Information Technologies," Int. J. Educ. Dev. using Inf. Commun. Technol., vol. 2, no. 1, pp. 17-30, 1997.

[20] International Telecommunication Union, "Country Profile- Sri Lanka," Country Profile, 2015. [Online]. Available: $\quad$ http://www.itu.int/net4/itud/icteye/CountryProfile.aspx. [Accessed: 19-Jan-2018].

[21] S. Lanka, "Computer Literacy Statistics - 2014 Department of Census and Statistics," 2014.

[22] S. A. Shonola, M. S. Joy, S. S. Oyelere, and J. Suhonen, "The Impact of Mobile Devices for Learning in Higher Education Institutions: Nigerian Universities Case Study," Int. J. Mod. Educ. Comput. Sci., vol. 8, no. 8, pp. 43-50, 2016.

[23] D. P. Nawinna and T. Halloluwa, "A Gamified Learning Tool for Sri Lankan Primary Schools," Proc. Natl. Conf. Technol. Manag., vol. 3, pp. 53-58, 2014.

[24] S. Price, C. Jewitt, and L. Crescenzi, "The role of iPads in pre-school children's mark making development," Comput. Educ., vol. 87, pp. 131-141, 2015.

[25] B. Beschorner and A. Hutchison, "iPads as a Literacy Teaching Tool in Early Childhood www.ijemst.com iPads as a Literacy Teaching Tool in Early Childhood iPads as a Literacy Teaching Tool in Early Childhood," Int. J. Educ. Math. Sci. Technol., vol. 1, no. 1, pp. 16-24, 2013.

[26] H. V Ramamoorthy, P. J. Balakumaran, and $\mathrm{H}$. Karthikeyani, "An Interactive Teaching - Learning Tool for Underprivileged Children in Rural Schools," Int. J. Mod. Educ. Comput. Sci., vol. 5, no. 7, pp. 27-33, 2013.

[27] T. Halloluwa, D. Vyas, H. Usoof, K. P. Hewagamage, and T. Sahama, "Gamifying Mathematics for Primary Students in Rural Sri Lanka," in Proceedings of the 9th Nordic Conference on Human-Computer Interaction, 2016, pp. 62-66.

[28] T. Halloluwa, D. Vyas, H. Usoof, and K. P. Hewagamage, "Gamification for development: a case of collaborative learning in Sri Lankan primary schools," Pers. Ubiquitous Comput., 2017.

[29] D. A. Grimes and K. F. Schulz, "Descriptive studies: what they can and cannot do," Lancet, vol. 359, pp. 145-149, 2002.

[30] A. Dissanayake, "ICT Education in Sri Lanka," Http://Info.Worldbank.Org/.

\section{Authors' Profiles}

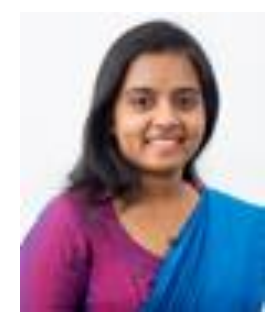

Pradeepa S. Bandara received the M.Sc degree in Information Technology specializing in Multimedia from University of Colombo School of Computing in Colombo, Sri Lanka. She received her B.Sc. Special honour degree in the field of Information Technology (IT) from Sri Lanka Institute of Information Technology (SLIIT) in Sri Lanka in 2011 with a first class.

She is a Researcher and Lecturer and currently works as Lecturer in Faculty of Computing, Department of Information Technology, Sri Lanka Institute of Information Technology (SLIIT) in Sri Lanka.

Her research interests are Human Computer Interaction, Software Engineering. She is a member of Computing Society of Sri Lanka (CSSL).

How to cite this paper: Pradeepa S. Bandara, "Inclination of Teachers towards Incorporating Mobile Game Based Learning into Primary Education: A Sri Lankan Case Study", International Journal of Information Technology and Computer Science(IJITCS), Vol.10, No.4, pp.66-72, 2018. DOI: 10.5815/ijitcs.2018.04.07 